\title{
SAIZ KOSA KATA DAN PENGETAHUAN KOLOKASI BAHASA ARAB DALAM KALANGAN PELAJAR SIJIL TINGGI AGAMA MALAYSIA (STAM)
}

\author{
Uraidah ABDUL WAHAB*1 \\ Mat Taib PA ${ }^{2}$ \\ Lily Hanefarezan ASBULAH ${ }^{3}$ \\ 12 Fakulti Bahasa dan Linguistik, Universiti Malaya \\ ${ }^{3}$ Fakulti Pengajian Islam, Universiti Kebangsaan Malaysia \\ 1uraidahabdulwahab@yahoo.com \\ ${ }^{2}$ mattaibpa@um.edu.my \\ 3 lilyhane@ukm.edu.my
}

Manuscript received 1 December 2020

Manuscript accepted 31 May 2021

${ }^{*}$ Corresponding author

https://doi.org/10.33736/ils.2794.2021

\begin{abstract}
ABSTRAK
Saiz dan kedalaman kosa kata merupakan dua disiplin ilmu yang mempunyai perkaitan. Keterbatasan kosa kata adalah antara punca kegagalan pelajar menguasai teks bacaan, berkomunikasi dan menghasilkan penulisan yang baik. Kajian ini bertujuan mengkaji hubungan antara saiz kosa kata dan pengetahuan kolokasi bahasa Arab. Dua set ujian iaitu; ujian saiz kosa kata dan ujian kolokasi bahasa Arab telah diedarkan kepada pelajar tingkatan enam yang mengambil subjek bahasa Arab di sekolah menengah agama di Malaysia. Kajian ini menggunakan persampelan bertujuan dengan memilih seramai 150 orang pelajar yang sedang mengikuti kurikulum Sijil Tinggi Agama Malaysia (STAM) dari empat buah Sekolah Agama Bantuan Kerajaan (SABK) di Perak. Dapatan kajian menunjukkan hubungan antara saiz kosa kata dan pengetahuan kolokasi bahasa Arab berkorelasi secara signifikan ( $r$ $=.76, p<.01$ ) bahkan perhubungan positif yang kuat. Namun, hasil nilai varians $r^{2}$ membuktikan bahawa hanya 57.7 peratus corak peningkatan faktor pengetahuan kolokasi bahasa Arab dijelaskan oleh perubahan corak saiz kosa kata, selebihnya oleh faktor lain yang tidak dapat dikesan. Penemuan kajian ini berjaya menonjolkan dapatan baharu bahawa peningkatan pengetahuan kolokasi bahasa Arab bukan diperoleh sepenuhnya melalui penguasaan saiz kosa kata. , Pelajar dan guru perlu memanfaatkan kepelbagaian strategi, pendekatan dan teknik dalam meningkatkan pengetahuan kolokasi bahasa Arab.
\end{abstract}

Kata kunci: Saiz kosa kata; pengetahuan kolokasi; bahasa Arab; korelasi 


\begin{abstract}
Vocabulary size and depth are two disciplines of vocabulary knowledge that are related. Limitations of vocabulary size are among the causes of students' failure in reading texts, communicate and produce good writing. This study aims to investigate the relationship between the Arabic vocabulary size and collocation knowledge. A set of Arabic vocabulary size test and another set of collocation test were distributed to form six students who took the Arabic language subject at religious secondary schools on Malaysia. This study uses purposive sampling to select 150 students who are following the Sijil Tinggi Agama Malaysia (STAM) curriculum from four Sekolah Agama Bantuan Kerajaan (SABK) schools in Perak. The findings show that the relationship between vocabulary size and Arabic collocation knowledge is significantly correlated $(r=.76, p<.01)$ and even a strong positive correlation. However, $r^{2}$ variance results prove that only 57.7 percent of the increasement pattern in Arabic collocation is explained by the changes in vocabulary size, the rest by other undetectable factors. Current study successfully highlights that the increase in Arabic collocation knowledge is not contributed completely through mastery of vocabulary size. Students and teachers need to utilise a variety of strategies, approaches and techniques in improving Arabic collocation knowledge.
\end{abstract}

Keywords: Vocabulary size; collocational knowledge; Arabic language; correlation

\title{
Pengenalan
}

Penyelidikan berkaitan pengetahuan kosa kata dalam pembelajaran bahasa kedua/asing semakin menarik perhatian para penyelidik terutama berkaitan perbezaan antara saiz atau keluasan kosa kata (breath of vocabulary) dan kedalaman kosa kata (depth of vocabulary) (Milton, 2009, hlm.13). Secara empirikal, saiz dan kedalaman kosa kata merupakan dua disiplin ilmu yang mempunyai perkaitan antara satu sama lain (Hellman, 2011; Koizumi \& In'nami, 2020; Schmitt, 2014; Webb, 2012; Vermeer, 2001). Menurut Hellman (2011), saiz kosa kata merujuk kepada aspek kuantiti, iaitu sejumlah kata yang dikenali oleh individu berdasarkan tahap kecekapan berbahasa. Konsep saiz kosa kata ini agak mudah difahami kerana pada dasarnya mengira jumlah item leksikal yang diketahui dan kebiasaannya melibatkan pengetahuan leksikal berhubung bentuk dan makna (Schmitt, 2014). Berdasarkan kajian terdahulu, tiada perdebatan dalam kalangan sarjana bahasa berkaitan konsep saiz kosa kata tetapi sebaliknya kepada konsep kedalaman kosa kata.

Konsep kedalaman kosa kata secara asasnya merujuk kepada aspek kualiti, iaitu berkaitan dengan cara penggunaan sesuatu kata dengan baik. Namun kaedah menyeluruh dalam menggariskan konsep kedalaman kosa kata adalah dengan mengklasifikasikannya kepada beberapa elemen tertentu (Schmitt, 2014). Terdapat empat elemen pengetahuan kata yang diklasifikasikan sebagai konsep kedalaman kosa kata. Empat elemen tersebut adalah: 
(a) penguasaan pelbagai aspek pengetahuan kata berikut; pengetahuan kolokasi (knowledge of collocation), pengetahuan bentuk derivatif (knowledge of derivative forms), dan pengetahuan makna polisemi (knowledge of polysemous meaning senses) (Schmitt, 2014, hlm. 922). Aspek pengetahuan kata ini berbeza berdasarkan konteks penggunaannya malah menguasai salah satu aspek sahaja masih dianggap penyumbang kepada kedalaman kosa kata

(b) penguasaan reseptif berbanding penguasaan produktif (receptive versus productive mastery); penguasaan reseptif adalah kemampuan memahami item leksikal semasa mendengar dan membaca, manakala penguasaan produktif adalah kemampuan menghasilkan item leksikal semasa bertutur dan menulis (Schmitt, 2014, hlm. 922),

(c) keupayaan menggunakan item leksikal secara lancar (the ability to use lexical items fluently). Kelancaran merupakan kriteria utama dalam meningkatkan kecekapan leksikal dalam komunikasi lisan dan tulisan (Schmitt, 2014, hlm. 922), dan

(d) keupayaan menguasai tahap dan jenis perkaitan antara item leksikal (the degree and kind of lexical organization) (Schmitt, 2014, hlm. 922).

Meara (1997) mencadangkan agar perkaitan antara item leksikal menjadi asas kepada penguasaan kemahiran reseptif dan produktif. Schmitt (2014) juga melihat wujudnya gabung jalin antara kesemua elemen ini dalam menjelaskan konsep kedalaman kosa kata. Ini menunjukkan bahawa konsep kedalaman kosa kata adalah kompleks dan merangkumi konstruk yang luas, hingga menyukarkan proses pengukuran. Oleh itu, kesesuaian pengukuran yang digunakan perlu diberi perhatian supaya dapat menentukan kewujudan perkaitan antara saiz dan kedalaman kosa kata atau tidak.

Namun, Vermeer (2001) mendapati adalah lebih baik sekiranya pengukuran hubungan saiz dan kedalaman kosa kata memberi fokus kepada penguasaan satu elemen kedalaman kosa kata sahaja bagi satu-satu masa pengukuran. Ini bertujuan untuk mendapatkan hasil pengukuran yang lebih spesifik dan mendalam. Kata kunci kepada hubungan antara saiz dan kedalaman kosa kata adalah tertakluk kepada pemahaman konsep dan kaedah pengukuran bagi kedua-dua aspek ini (Schmitt, 2014). Justeru, dalam kajian ini pengkaji memberi tumpuan kajian kepada hubungan saiz kosa kata bahasa Arab dan memilih penguasaan pengetahuan kolokasi dalam kalangan pelajar sekolah menengah yang mengambil subjek bahasa Arab sebagai elemen kedalaman kosa kata yang dikaji.

\section{Saiz kosa kata Bahasa Arab}

Aspek penting yang dianggap sebagai penunjuk kepada tahap penguasaan seseorang individu dalam kemahiran bahasa adalah saiz kosa kata (Nation, 2001). Malah, aspek ini merupakan prasyarat kepada pelajar bahasa asing untuk meningkatkan 
penguasaan dan mengembangkan potensi bahasa tersebut (Read, 2000; Ta'imah, 2001). Walau bagaimanapun, pengkaji bahasa mempunyai pandangan yang berbeza mengenai isu kuantiti kosa kata. Kajian Nation (2001) yang berasaskan kekerapan penggunaan menunjukkan bahawa sekitar 2000 kata asas adalah jumlah yang perlu dikuasai pelajar bahasa asing untuk memahami 80 peratus kefahaman teks pelbagai genre penulisan dan pertuturan. Dapatan ini selari dengan beberapa kajian lain (Nation \& Waring, 2001; Schmitt, 2000). Jumlah kosa kata asas ini adalah realistik sebagai langkah pertama dalam mempelajari bahasa, memahami teks atau berkomunikasi (Meara \& Alcoy, 2010) serta melayakkan diri mengikuti pengajian di peringkat tinggi (Schmitt, 2000).

Namun, bagi pembelajaran yang lebih mendalam, kosa kata akademik perlu diberi penekanan serius bagi membantu pelajar memahami teks-teks akademik (Nation, 2001). Begitu juga di peringkat universiti, penguasaan kosa kata teknikal dalam bidang pengkhususan dilihat amat penting (Razak et al., 2015) di samping kosa kata berkekerapan tinggi dan kosa kata akademik. Di Malaysia, Bahagian Pembangunan Kurikulum, Kementerian Pendidikan Malaysia (KPM) telah menentukan kuantiti sasaran bagi kosa kata yang perlu dicapai dalam objektif pembelajaran bahasa Arab malah kuantiti ini berbeza mengikut setiap peringkat. Dalam erti kata lain, saiz kosa kata sedia ada perlu dikenal pasti sebelum pendedahan sesuatu kemahiran bahasa dan juga sebelum menyambung pengajian ke peringkat yang seterusnya. Penilaian ini bertujuan memastikan pelajar yang bakal mengambil peperiksaan Sijil Tinggi Agama Malaysia (STAM) mempunyai sejumlah kosa kata asas yang mencukupi berdasarkan tahap pembelajaran yang akan dilaluinya.

Walau bagaimanapun, isu kelemahan kosa kata Arab telah dikenal pasti berlaku di semua peringkat pembelajaran; sekolah menengah (Zaid et al., 2016), pra universiti (Baharudin \& Ismail, 2014; Samah, 2012) serta berterusan di peringkat pengajian tinggi (Hazwan, et al., 2018; Zaini \& Abd Rahman, 2017).

Secara lebih terperinci, Baharudin dan Ismail (2014) membuktikan bahawa saiz kosa kata bahasa Arab bagi pelajar prauniversiti secara puratanya hanya menguasai 717 kata daripada 4000 kata. Ini menunjukkan jumlah yang kecil dan tidak mencapai paras minimum berdasarkan ketetapan beberapa kajian terhadap saiz kosa kata yang perlu dikuasai oleh pelajar bahasa asing (Meara \& Alcoy, 2010; Nation, 2001; Read, 2000; Schmitt, 2000). Manakala pelajar kolej universiti Islam dalam jurusan pengajian Islam dan bahasa Arab memiliki jumlah kosa kata Arab sebanyak 1231 kata secara puratanya (Zaini \& Abd Rahman, 2017). Namun jumlah ini dianggap masih belum mencukupi bagi pelajar pengkhususan bahasa Arab terutama untuk menguasai teks bacaan, berkomunikasi dan menghasilkan penulisan yang baik.

Oleh sebab terdapatnya hubungan yang kuat antara saiz kosa kata dengan kemahiran bahasa, maka keterbatasan saiz kosa kata menjadi salah satu punca utama kegagalan pelajar dalam penguasaan pelbagai kemahiran bahasa; membaca (Abdul Ghani, 2011), bertutur (Zaini \& Abd Rahman, 2017), berkomunikasi (Aladdin, 2012; Yusri et. al., 2011; Nadwah \& Nadhilah, 2014), membina ayat (Samah, 2012) bahkan tidak berupaya mempelbagaikan strategi pembelajaran kosa kata (Harun \& Maimun, 2017) dalam kalangan pelajar bahasa Arab di Malaysia. Justeru, kegagalan 
menguasai kemahiran bahasa turut mempengaruhi pencapaian akademik pelajar (Laufer \& Nation, 2013).

Saiz kosa kata turut dicadangkan sebagai penanda aras kepada penguasaan pengetahuan kolokasi dalam pembelajaran bahasa bahasa asing (Bergström, 2008; Gyllstad, 2007; Kadlecová, 2014; Mutlu \& Kaşlıoğlu, 2016). Dapatan kajian Gyllstad (2007) dan Bergström (2008) membuktikan bahawa pengetahuan kolokasi bahasa Inggeris dalam kalangan penutur bukan natif mempunyai korelasi yang positif dengan saiz kosa kata berdasarkan ujian kolokasi reseptif dan ujian saiz kosa kata yang diuji ke atas pelajar Sweden. Begitu juga dapatan yang sama diperoleh melalui kajian Kadlecová (2014) ke atas pelajar Slovak dan kajian Mutlu dan Kaşlığlu (2016) ke atas pelajar Turki. Dapatan kajian Laufer dan Waldman (2011) mendapati pelajar bukan natif yang memiliki saiz kosa kata bahasa asing antara 3,000 hingga 10,000 kata, mampu menguasai pengetahuan kolokasi dengan baik tetapi belum mampu menggunakannya dalam penulisan terbuka.

\section{Pengetahuan kolokasi Bahasa Arab}

Kolokasi terdapat dalam semua bahasa termasuk bahasa Arab. Namun, setiap bahasa memiliki ciri kolokasi yang tertentu. Kolokasi didefinisikan sebagai urutan kata yang kerap dilihat beriringan. Istilah kolokasi dinyatakan dalam Oxford Collocation Dictionary (2002, hlm. vii) sebagai gabungan beberapa kata untuk membina ungkapan dalam suatu bahasa sama ada pertuturan atau penulisan seperti penutur jati. Para sarjana bahasa Arab memperkenalkan beberapa istilah bagi menjelaskan konsep kolokasi. Antaranya, الرَضْف (al-rasf) oleh Umar (1998), المُتَلَازِمَاتُ اللَفْظِيَّةُ (al-mutalazimat al-lafziyyah) oleh Said (2014) dan المُتَضَاحِبَات (al-mutasahibat) oleh al-Tahir 'Abd al-Salam (2004). Said (2014, hlm. 5) mentakrifkan kolokasi sebagai gabungan kata yang tidak boleh ditukar ganti seperti ungkapan tetap dan idiom.

Santillán Grimm (2009) pula meletakkan kedudukan kolokasi selepas ungkapan tetap dan idiom berdasarkan aras ketetapan, manakala sebelum kombinasi terbuka pada aras kesukaran. Kolokasi lebih bebas daripada ungkapan tetap dan idiom dari aspek sintaksis tetapi lebih mudah dari aspek semantik (Santillán Grimm, 2009). Contohnya, أَكلة اللحم pemakan daging adalah idiom yang

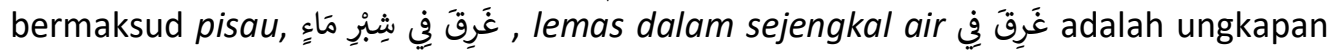

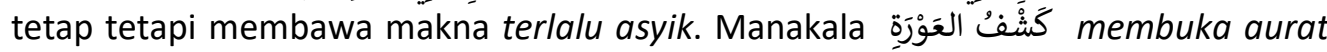

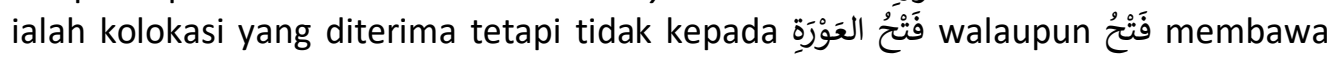
makna membuka. Maka, makna kolokasi lebih mudah difahami melalui kata yang berkolokasi walaupun sedikit terikat kepada ketetapan tertentu. Sebaliknya, kombinasi terbuka pula sangat mudah difahami maknanya dan mempunyai kebebasan mutlak dari aspek susunan dalam ayat. Contohnya, مَدْرََةٌْ جَمِيلَة (sekolah cantik) adalah kombinasi terbuka, kata nama مَنْرَسَة (sekolah) boleh dikombinasikan

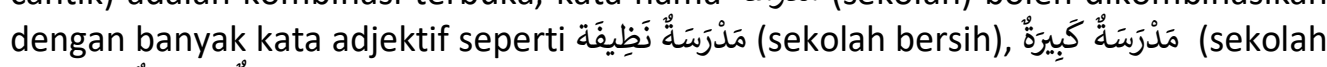
besar), مَدْرَسَةُ صَغِيَرَة (sekolah kecil) dan sangat mudah untuk memahami makna kombinasi kata tersebut.

Kecekapan kolokasi dianggap penentu kepada penguasaan seseorang pelajar dalam bahasa kedua atau bahasa asing (Hill, 2000; Lewis, 2000; Mansoor,2019; 
Nation, 2001; Wray, 2002). Lewis (2000) melihat pelajar bahasa kedua yang berada pada tahap pertengahan dan tinggi lebih memerlukan pengetahuan kolokasi agar dapat menguasai kemahiran bahasa sasaran yang lebih mencabar berbanding pelajar tahap asas. Terdapat banyak penyelidikan yang dijalankan untuk menilai pengetahuan kolokasi dalam kalangan pelajar bahasa kedua atau asing, serta mengenal pasti teknik yang berkesan dalam meningkatkan kecekapan kolokasi pelajar (Bağci, 2014; Basal, 2019; Fernández \& Schmitt, 2015; Mansoor, 2019; Nizonkiza, 2012; Siyanova \& Schmitt, 2008; Sonbul \& Schmitt, 2013).

Isu keterbatasan saiz kosa kata turut membawa pengkaji menerokai dan memahami permasalahan asas berkaitan hubungan saiz dan kedalaman kosa kata. Schmitt (2010) menegaskan bahawa kegagalan pelajar mencapai saiz kosa kata sasaran adalah disebabkan terlalu memberi tumpuan kepada penguasaan kata tunggal (single word) berbanding kata yang berkolokasi. Justeru, cadangan Bahns dan Eldaw (1993) serta Hill (2000) agar perluasan pengetahuan kosa kata sedia ada melalui pembelajaran kolokasi wajar dilaksanakan dalam pembelajaran bahasa asing berbanding penekanan kepada hafalan kosa kata semata-mata. Bahkan pengetahuan kolokasi dilihat sebagai penyumbang kepada kedalaman pengetahuan kosa kata (Schmitt, 2014).

Secara keseluruhannya, dapatan kajian lepas menunjukkan bahawa tahap pengetahuan kolokasi dalam kalangan pelajar bahasa kedua/asing adalah lemah. Kolokasi dikategorikan sebagai aspek yang sukar dikuasai pelajar dan menjadi faktor kepada kelemahan berkomunikasi dalam bahasa sasaran. Di samping itu, kajian perbandingan mendapati pelajar mempunyai pengetahuan kolokasi reseptif yang lebih luas berbanding kolokasi produktif (Bağci, 2014; Siyanova \& Schmitt, 2008; Sonbul \& Schmitt, 2013). Manakala, kecekapan kolokasi pelajar di peringkat lanjutan lebih baik berbanding pelajar di peringkat pramenengah (Bağcl, 2014).

Walau bagaimanapun, di Malaysia, fenomena kolokasi dalam pembelajaran bahasa Arab merupakan aspek yang kurang mendapat perhatian berbanding aspek tatabahasa (Abdul Wahab, 2014). Ini menimbulkan kelemahan pengetahuan dan kecekapan kolokasi dalam kalangan pelajar bahasa Arab. Aspek kolokasi bahasa Arab mula diberi perhatian oleh penyelidik (Abdul Wahab, 2014; Absulah et al., 2019; Aladdin, 1998; Mohamad \& Mezah, 2007; Nawi \& Zainuddin, 2018). Beberapa kelemahan telah dikenal pasti antaranya; kesilapan ketika menggunakan kata nama, kata kerja dan partikel yang tepat (Mohamad \& Mezah, 2007), tidak cekap dalam memilih dan memadan kata yang sesuai mengikut konteks ayat (Mezah, 2009; Mohamad \& Mezah, 2007; Nawi \& Zainuddin, 2018;) malah wujud kekeliruan berkaitan kolokasi jenis kata nama+kata nama (al-idafat) dan kolokasi kata nama+kata adjektif (al-na'at) (Abdul Wahab, 2014; Aladdin, 1998; Halim, 2002). Walau bagaimana pun, tiada perbahasan berkaitan hubungan saiz kosa kata dan pengetahuan kolokasi bahasa Arab ditemui. Maka, aspek ini menarik perhatian pengkaji untuk mendapatkan solusi dan penjelasan terhadap isu keterbatasan saiz kosa kata dan hubungannya dengan pengetahuan kolokasi di samping mengisi kelompangan kajian dalam pembelajaran bahasa Arab yang masih belum diterokai. Oleh itu, kajian ini bertujuan untuk mengkaji hubungan antara saiz kosa kata dan pengetahuan kolokasi bahasa Arab. Kajian ini akan ditumpukan untuk menjawab soalan-soalan berikut: 
1. Apakah tahap saiz kosa kata bahasa Arab dalam kalangan pelajar STAM?

2. Apakah tahap pengetahuan kolokasi bahasa Arab dalam kalangan pelajar STAM?

3. Apakah hubungan antara saiz kosa kata bahasa Arab dan pengetahuan kolokasi bahasa Arab dalam kalangan pelajar STAM?

\section{Metodologi Kajian}

Kajian ini ialah kajian kuantitatif berbentuk korelasi bertujuan menentukan hubungan antara dua pemboleh ubah iaitu saiz kosa kata bahasa Arab dan pengetahuan kolokasi bahasa Arab. Sampel kajian terdiri daripada 150 orang pelajar yang sedang mengikuti kurikulum Sijil Tinggi Agama Malaysia di empat buah Sekolah Agama Bantuan Kerajaan (SABK) di negeri Perak. Pemilihan sampel dilakukan melalui kaedah persampelan bertujuan. Sampel dipilih kerana memenuhi kriteria kehendak kajian, kesediaan pelajar dan sekolah yang menyertai kajian ini, mudah diakses dan mendapat kebenaran daripada pihak pentadbiran sekolah berkenaan. Terdapat dua instrumen digunakan dalam kajian ini. Pertama, ujian saiz kosa kata bahasa Arab Harun (2014) digunakan untuk mengukur tahap saiz kosa kata bahasa Arab. Kedua, ujian kolokasi bahasa Arab yang bertujuan mengukur tahap pengetahuan kolokasi bahasa Arab.

Ujian saiz kosa kata Harun (2014) telah melalui proses penyemakan panel pakar dan ujian ketekalan. Hasil ujian ketekalan menunjukkan nilai korelasi yang tinggi iaitu $r=.84, p<.001$, pekali alfa Cronbach yang tinggi iaitu .89 dan pekali Cohen Kappa juga tinggi iaitu .95. Di samping itu, instrumen ini telah diuji ke atas pelajar tingkatan enam di SMKA dan SABK yang sama dengan kajian ini. Maka, pemilihan menggunakan instrumen ini adalah tepat dengan objektif kajian dan sesuai dengan tahap penguasaan bahasa sampel kajian ini.

Format ujian ini berbentuk dwibahasa. Responden dikehendaki menjawab makna perkataan dalam bahasa Melayu berdasarkan konteks ungkapan yang dikemukakan iaitu berbentuk ayat, petikan ayat al-Quran dan frasa. Format ini bertujuan untuk membantu pelajar agar lebih yakin dalam menyatakan pemahaman mereka tentang perkataan sasaran tanpa dihalang oleh kekurangan pengetahuan sinonim perkataan dan frasa bahasa Arab. Ujian ini menguji kosa kata asas berdasarkan senarai kekerapan kata yang diwakili oleh empat tahap kekerapan kata iaitu tahap 1000 kata, tahap 2000 kata, tahap 3000 kata dan tahap 4000 kata. Keputusan indeks kesukaran dan indeks diskriminasi item menetapkan setiap tahap diwakili oleh 10 kata yang terdiri daripada kata nama, kata kerja dan partikel. Ini menjadikan jumlah keseluruhan item ujian kosa kata ialah 40 kata yang dipilih bagi mewakili 4000 kata. Bagi tujuan pengiraan skor ujian ini, setiap perkataan yang dijawab dengan betul diberikan satu markah. Jumlah bilangan perkataan yang dijawab dengan betul ialah skor ujian.

Ujian kolokasi bahasa Arab ini dibina berdasarkan dimensi penilaian kosa kata Read (2000:9) dengan mengambil tiga langkah iaitu pertama "discrete", membina ujian kolokasi bahasa Arab secara berasingan daripada ujian kemahiran 
berbahasa yang lain, kedua "selective", memilih kosa kata tertentu dan jenis kolokasi tertentu yang bersesuaian dengan tahap keupayaan sampel kajian dan ketiga "context-dependent", memilih ujian kolokasi bahasa Arab yang bersandarkan kepada konteks tertentu agar mudah ditadbir dan dapat menghasilkan data interval melalui analisis kuantitatif yang dilaksanakan.

Ujian ini mengukur lima elemen pengetahuan kolokasi bahasa Arab dengan merujuk domain kognitif Taksonomi Objektif Pendidikan Bloom (1956) yang telah disemak semula oleh Anderson dan Krathwohl (2001). Setiap elemen mengandungi sembilan item yang terdiri daripada tiga kolokasi Kata Nama+Kata Nama (al-idafah), tiga kolokasi Kata Nama+Kata Adjektif (al-na'at) dan tiga kolokasi Kata Kerja+Kata Nama (al-maf'ul). Ini menjadikan jumlah kolokasi sasaran bagi kelima-lima eleman pengetahuan kolokasi bahasa Arab adalah sebanyak 45 item. Senarai kekerapan perkataan (frequency word list) Abdul Rahman Chik (1994) sebagai asas dalam pemilihan kosa kata dan kolokasi sebagai sampel ujian ini.

Sebelum instrumen diedarkan, instrumen telah melalui proses kesahan kandungan bersama tujuh orang panel pakar yang dipilih. Pakar-pakar tersebut terdiri daripada pensyarah kanan di universiti, pegawai bahasa Arab di Lembaga Peperiksaan, Kementerian Pelajaran Malaysia (KPM) serta guru bahasa Arab yang mengajar subjek STAM. Pemilihan panel pakar ini adalah berdasarkan kepakaran mereka dalam bidang linguistik Arab dan pengalaman mereka yang melebihi 10 tahun terutamanya dalam aspek kolokasi bahasa Arab, pendidikan bahasa Arab dan pembinaan soal selidik. Panel pakar diminta untuk menyemak, memberi pandangan dan cadangan terhadap kandungan soal selidik, meneliti setiap item berkaitan kesesuaian kata yang dipilih, aras kesukaran soalan, konstruk yang diuji, laras bahasa yang digunakan serta keupayaannya untuk ditadbir bagi sampel kajian yang dipilih.

Manakala kebolehpercayaan instrumen ditentukan melalui ujian kebolehpercayaan uji-uji semula (test-retest). Hasil ujian menunjukkan hubungan positif yang kuat antara lima elemen pengetahuan kolokasi bahasa Arab dalam kedua-dua ujian ( $r=.94, .88, .89, .90$ dan .94, $\mathrm{n}=30, p=.000)$. Manakala nilai pekali kebolehpercayaan alfa Cronbach adalah .72 bagi rintis 1 dan .70 bagi rintis 2. Nilai ini berada pada tahap stabil (stability coefficients) iaitu antara $\alpha=.60$ hingga $\alpha=.95$. Nilai ini menunjukkan bahawa ujian kolokasi bahasa Arab mempunyai nilai ketekalan yang memuaskan dan sekali gus item yang dibina boleh diterima (Chua, 2014; Konting, 1993; Nunally, 1978). Hasil pengiraan nilai KR20 pula bagi keseluruhan item ujian rintis kolokasi bahasa Arab ialah 0.724. Nilai ini berada antara 0.70 hingga 1.00 membuktikan bahawa item tersebut mempunyai ketekalan yang baik seperti saranan daripada Texas Education Agency (2002). Nilai KR20 yang semakin tinggi membuktikan hubungan antara item-item dalam ujian semakin kuat. Maka, item instrumen ujian KBA ini boleh diterima.

Semua data ujian saiz kosa kata dan ujian kolokasi bahasa Arab yang diperoleh, dikumpul dan dianalisis. Proses analisis dijalankan menggunakan statistik deskriptif dan statistik inferensi berbantukan perisian "Statistical Package for The Social Science" (SPSS) versi 25.0. 


\section{Dapatan Kajian}

Kajian ini menggunakan nilai interpretasi tahap skor min yang digariskan oleh Nunally dan Bernstein (1994) yang membawa tafsiran skor ujian saiz kosa kata bahasa Arab dan ujian kolokasi bahasa Arab berada pada tahap tinggi, sederhana, sederhana rendah dan rendah (Rujuk kepada Lampiran). Manakala nilai interpretasi skor min Ahmad dan Meerah (2002) bagi tafsiran skor setiap elemen pengetahuan kolokasi (rujuk Lampiran 1). Kekuatan perhubungan antara pemboleh ubah dalam kajian ini berpandu kepada Nilai Panduan Linear Pearson ' $r$ ' yang dicadangkan oleh Hair, Wolfinberger, Ortinau, dan Bush (2010) (rujuk Lampiran 1).

\section{Tahap saiz kosa kata bahasa Arab}

Tahap saiz kosa kata bahasa Arab dalam kalangan subjek kajian $(n=150)$ adalah berdasarkan skor pencapaian dalam ujian saiz kosa kata bahasa Arab. Berdasarkan Rajah 1, kajian ini mendapati bahawa skor pencapaian saiz kosa kata bahasa Arab antara 0-10 (0-1000 perkataan) ialah seramai 49 orang (32.7\%), skor pencapaian antara 11-20 (1001-2000 perkataan) seramai 92 orang (61.3\%) dan skor pencapaian antara 21-30 (2001-3000 perkataan) pula ialah seramai 9 orang (6.0\%). Sementara itu, tiada seorang pun pelajar yang memperoleh skor pencapaian antara 31-40 (3001-4000 perkataan). Hal ini menunjukkan penguasaan saiz kosa kata bahasa Arab majoriti sampel responden pelajar STAM (61.3\%) berada pada tahap sederhana rendah.

\section{Rajah 1}

Taburan Pelajar Berdasarkan Tahap Saiz Kosa Kata Bahasa Arab

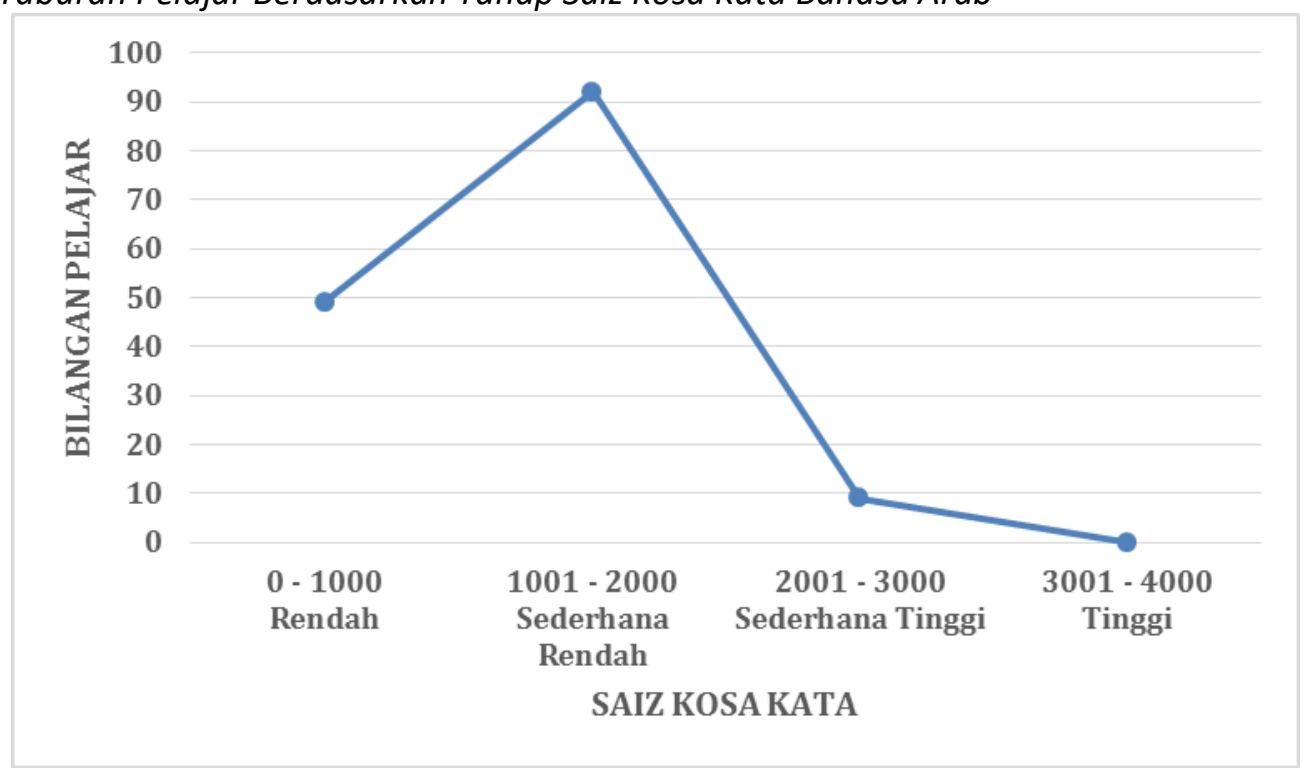


Jadual 1

Min dan Sisihan Piawai berdasarkan Tahap Saiz Kosa Kata Bahasa Arab

\begin{tabular}{lccc}
\hline Tahap Saiz Kosa Kata & $n$ & Min & Sisihan Piawai \\
\hline Rendah & 49 & 9.35 & .779 \\
Sederhana rendah & 92 & 14.26 & 2.647 \\
Sederhana tinggi & 9 & 22.67 & 1.414 \\
\hline Saiz kosa kata keseluruhan & 150 & 13.16 & 3.946 \\
\hline
\end{tabular}

Data statistik dalam Jadual 1, menunjukkan bahawa nilai skor min keseluruhan bagi tahap penguasaan saiz kosa kata bahasa Arab pula ialah 13.16 dengan sisihan piawai 3.946. Manakala skor min dan sisihan piawai bagi tahap rendah $(M=9.35 ; S D=.779)$, tahap sederhana rendah $(M=14.26 ; S D=2.647)$ dan tahap sederhana tinggi $(M=22.67 ; S D=1.414)$. Dapatan ini juga menjelaskan bahawa secara purata, pelajar tahap rendah menguasai 935 kata, pelajar tahap sederhana rendah menguasai 1,426 kata dan pelajar tahap sederhana tinggi menguasai 2267 kata daripada 4000 kata. Data menunjukkan peningkatan saiz kosa kata bahasa Arab yang konsisten berdasarkan tahap pelajar. Berdasarkan jumlah skor pelajar secara keseluruhan iaitu 1,974, maka purata penguasaan saiz kosa kata bahasa Arab dalam kalangan 150 sampel pelajar STAM di SABK ialah sebanyak 1,316 daripada 4000 perkataan.

\section{Tahap pengetahuan kolokasi bahasa Arab}

Tahap pengetahuan kolokasi bahasa Arab dalam kalangan subjek kajian $(n=150)$ dinilai berdasarkan skor pencapaian pelajar dalam ujian kolokasi bahasa Arab. Rajah 2 menjelaskan bahawa tahap pengetahuan kolokasi bahasa Arab dalam kalangan subjek kajian hanya berada pada dua tahap sahaja iaitu; tahap rendah yang diwakili oleh 59 orang pelajar (39.3\%) dan tahap sederhana rendah seramai 91 orang pelajar (60.7\%). Sebaliknya tiada pelajar yang mewakili tahap sederhana tinggi dan tahap tinggi. Secara keseluruhannya, dapatan ini menunjukkan bahawa majoriti sampel responden pelajar STAM (60.7\%) berada pada tahap sederhana rendah. 


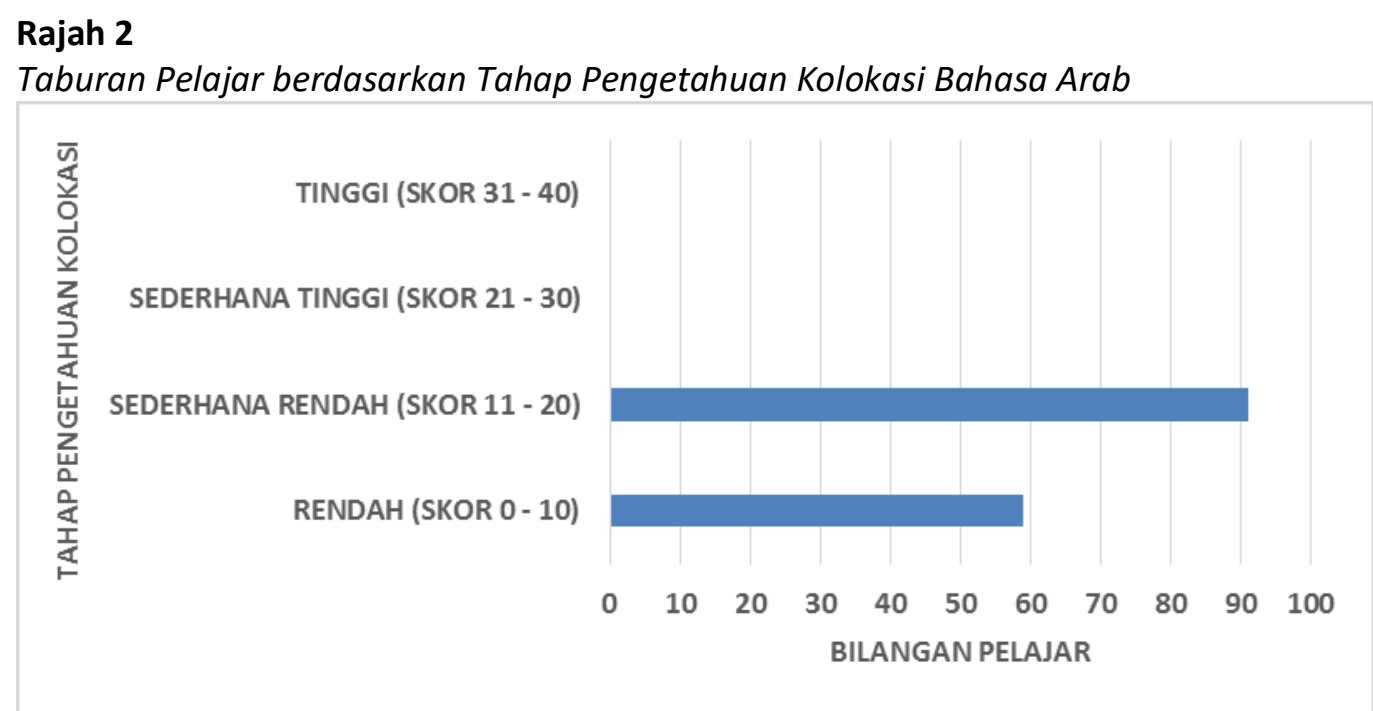

Nilai skor min dan sisihan piawai bagi tahap pengetahuan kolokasi bahasa Arab secara keseluruhan dan terperinci ditunjukkan dalam Jadual 2. Nilai skor min dan sisihan piawai bagi tahap pengetahuan kolokasi bahasa Arab secara keseluruhan adalah $(M=13.14 ; S D=2.776)$. Manakala perincian dapatan menjelaskan bahawa subjek kajian ini mempunyai pengetahuan kolokasi bahasa Arab yang sederhana dalam elemen perkaitan makna antara perkataan $(M=4.24, S D=.808)$, manakala empat elemen yang lain pada tahap rendah iaitu; elemen pemillihan kolokasi yang tepat dalam konteks $(M=2.66, S D=1.469)$, diikuti eleman pemilihan kolokasi tunggal yang tepat $(M=2.47, S D=.946)$, elemen perluasan makna kosa kata sedia ada $(M=2.29, S D=.822)$ dan yang paling rendah adalah elemen penggunaan kata yang tepat dalam konteks $(M=1.49, S D=.766)$.

\section{Jadual 2}

Skor Min dan Sisihan Piawai berdasarkan Elemen Pengetahuan Kolokasi Bahasa Arab

\begin{tabular}{|c|c|c|c|c|}
\hline Elemen Pengetahuan Kolokasi & $n$ & Min & $\begin{array}{l}\text { Sisihan } \\
\text { Piawai }\end{array}$ & $\begin{array}{c}\text { Interpretasi } \\
\text { tahap }\end{array}$ \\
\hline Perkaitan makna antara perkataan & 150 & 4.24 & .808 & sederhana \\
\hline Perluasan makna kosa kata sedia ada & 150 & 2.29 & .822 & rendah \\
\hline Pemilihan kolokasi tunggal yang tepat & 150 & 2.47 & .946 & rendah \\
\hline Penggunaan kata yang tepat dalam konteks & 150 & 1.49 & .766 & rendah \\
\hline Pemilihan kolokasi yang tepat dalam konteks & 150 & 2.66 & 1.469 & rendah \\
\hline $\begin{array}{l}\text { Pengetahuan Kolokasi Bahasa Arab } \\
\text { (Keseluruhan) }\end{array}$ & 150 & 0.1 & 2.776 & $\begin{array}{l}\text { sederhana } \\
\text { rendah }\end{array}$ \\
\hline
\end{tabular}




\section{Hubungan antara saiz kosa kata bahasa Arab dan pengetahuan kolokasi bahasa Arab}

Pearson product-moment correlation coefficient ditadbir bagi mengenal pasti hubungan antara pemboleh ubah bebas; saiz kosa kata bahasa Arab dan pemboleh ubah bersandar; pengetahuan kolokasi bahasa Arab dalam kalangan pelajar STAM. Hubungan antara saiz kosa kata dan pengetahuan kolokasi bahasa Arab dalam kalangan subjek kajian ini dijelaskan melalui garis regresi dalam Scatterplot di Rajah 3 dan nilai pekali korelasi dalam Jadual 3.

Garis regresi dalam Scatterplot menunjukkan tinggi di sebelah kanan, manakala taburan titik skor mengikut arah garis regresi tersebut. Maka hubungan antara dua pemboleh ubah ini adalah positif dan mewakili perhubungan "semakin tinggi saiz kosa kata, semakin tinggi pengetahuan kolokasi". Seterusnya, Jadual 5 menjelaskan nilai pengukuran kekuatan perhubungan antara dua pemboleh ubah ini. Nilai pekali korelasi saiz kosa kata bahasa Arab $(M=13.16, S D=3.94)$ dan pengetahuan kolokasi bahasa $\operatorname{Arab}(M=13.14, S D=2.776)$ bagi sampel kajian ini ( $n$ $=150$ ) adalah $r=.76, p=.000$. Berdasarkan Nilai Panduan Linear Pearson ' $r$ ' yang dicadangkan oleh Hair et. al (2010), pekali korelasi $r=.76$ menunjukkan terdapat perhubungan yang signifikan antara saiz kosa kata bahasa Arab dan pengetahuan kolokasi bahasa Arab bahkan perhubungan itu adalah kuat.

\section{Rajah 3}

Korelasi antara Saiz Kosa Kata dan Pengetahuan Kolokasi Bahasa Arab

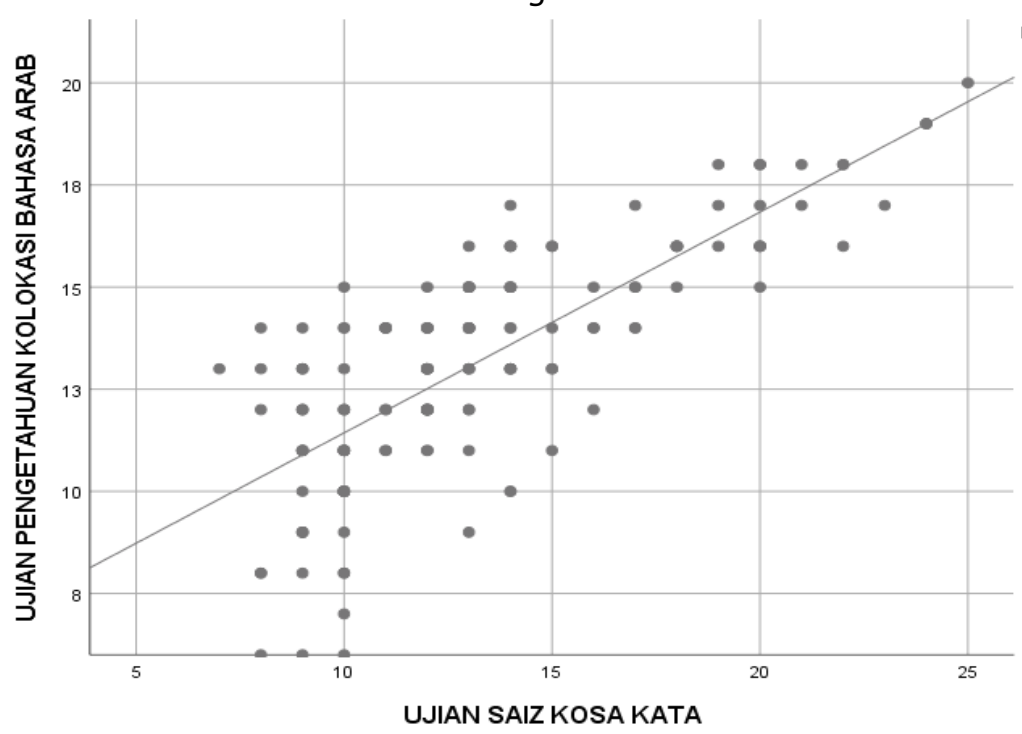


Jadual 3

Korelasi antara Saiz Kosa Kata Bahasa Arab dan Pengetahuan Kolokasi Bahasa Arab

\begin{tabular}{llcc}
\hline & & $\begin{array}{c}\text { Pengetahuan } \\
\text { Kolokasi Bahasa } \\
\text { Arab }\end{array}$ & $\begin{array}{c}\text { Saiz kosa kata } \\
\text { bahasa Arab }\end{array}$ \\
\hline Saiz kosa kata bahasa Arab & $\begin{array}{l}\text { Pearson } \\
\text { Correlation } \\
\text { Sig. (2-tailed) }\end{array}$ & $.768^{* *}$ & 1 \\
& $N$ & .000 & \\
Pengetahuan Kolokasi & Pearson & 150 & 150 \\
Bahasa Arab & $\begin{array}{l}\text { Correlation } \\
\text { Sig. (2-tailed) }\end{array}$ & & $.768^{* *}$ \\
& $N$ & 150 & .000 \\
& & & 150 \\
\hline
\end{tabular}

** Correlation is significant at the 0.01 level (2-tailed)

Walau bagaimanapun, nilai $r=.76$ tidak menunjukkan satu perhubungan sekuat $76 \%$ antara kedua-dua pemboleh ubah. Hal ini kerana, pekali $r$ merupakan satu nilai relatif yang digunakan sebagai perbandingan kekuatan perhubungan antara pemboleh ubah. Justeru, untuk melihat sumbangan saiz kosa kata bahasa Arab kepada pengetahuan kolokasi bahasa Arab, nilai varians $r^{2}$ digunakan. Maka dalam kajian ini, varians $r^{2}=.76^{2}=.577$ menunjukkan bahawa $57.7 \%$ corak peningkatan faktor pengetahuan kolokasi bahasa Arab dalam kalangan pelajar dijelaskan oleh perubahan corak saiz kosa kata bahasa Arab yang dimiliki mereka. Manakala 42.3\% lagi adalah berdasarkan faktor lain yang tidak dapat dikesan.

Perincian perhubungan antara saiz kosa kata dengan lima elemen pengetahuan kolokasi bahasa Arab dijelaskan dalam Jadual 4. Hasil analisis interkorelasi menunjukkan hubungan yang signifikan antara saiz kosa kata bahasa Arab dan semua elemen pengetahuan kolokasi bahasa Arab. Empat elemen mempunyai nilai korelasi yang sederhana iaitu perkaitan makna antara perkataan ( $r=.40$; $p=.000)$, perluasan makna kosa kata sedia ada $(r=.42 ; p=.000)$, penggunaan kata yang tepat dan sesuai dalam konteks $(r=.47 ; p=.000)$ dan pemilihan kolokasi yang tepat dan sesuai dalam konteks $(r=.49 ; p=.000)$. Manakala elemen pemilihan kolokasi tunggal yang tepat sahaja mempunyai nilai pekali korelasi yang lemah $(r=.38$; $p=.000)$.

Jadual 4

Korelasi antara Saiz Kosa Kata Bahasa Arab dan Elemen Pengetahuan Kolokasi Bahasa Arab

\begin{tabular}{cccccc}
\hline & Elemen & Elemen 2 & Elemen 3 & Elemen 4 & Elemen 5 \\
\hline & Perkaita & Perluasan & Pemilihan & Penggunaa & Pemilihan \\
& n makna & kolokasi & n kata yang & kolokasi \\
& antara & makna & tunggal & tepat & yang tepat \\
& perkata & kosa kata & yang & dalam & dalam \\
& an & sedia ada & tepat & konteks & konteks \\
\hline & & & $.381^{* *}$ & $.474^{* *}$ & $.499 * *$
\end{tabular}




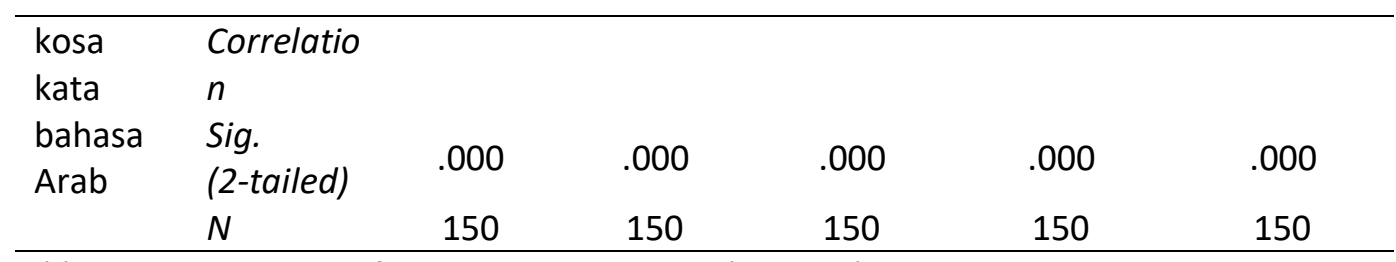

** Correlation is significant at the 0.01 level (2-tailed)

\section{Perbincangan Dapatan}

Dapatan kajian pertama menunjukkan bahawa tahap saiz kosa bahasa Arab bagi 61.3\% sampel pelajar STAM adalah sederhana rendah secara purata berada dalam lingkungan 1,316 daripada 4000 perkataan. Jumlah ini dianggap berada bawah paras minimum berdasarkan ketetapan yang digariskan oleh beberapa kajian lepas terhadap tahap kosa kata dalam kalangan pelajar bahasa asing (Meara, 2001; Nation, 2001; Read, 2000; Schmitt, 2000). Dengan saiz kosa kata ini, sampel responden pelajar STAM dijangka kurang berkemampuan untuk mencapai had kecekapan umum bahasa (Meara, 2001; Nation, 2001) khususnya dalam aspek kedalaman kosa kata seperti pengetahuan kolokasi. Dapatan ini turut selari dengan dapatan beberapa kajian yang dijalankan dalam konteks pembelajaran bahasa kedua (Bergström, 2008; Gyllstad, 2007; Kadlecová, 2014; Mutlu \& Kaşlıoğlu, 2016) dan konteks pembelajaran bahasa Arab sebagai bahasa asing (Baharudin \& Ismail, 2014; Zaini \& Abd Rahman, 2017).

Fokus kedua kajian ini adalah mengenal pasti tahap pengetahuan kolokasi bahasa Arab. Hasil kajian menunjukkan pengetahuan kolokasi bahasa Arab majoriti pelajar $(60.7 \%)$ berada pada tahap sederhana rendah. Tahap pengetahuan kolokasi ini mengukuhkan bahawa aspek kedalaman kosa kata ini antara aspek yang sukar dikuasai pelajar bahasa asing (Bağcı, 2014; Siyanova \& Schmitt, 2008; Sonbul \& Schmitt, 2013). Perincian dapatan kajian juga membuktikan bahawa empat elemen pengetahuan kolokasi bahasa Arab masih pada tahap rendah iaitu elemen pemillihan kolokasi yang tepat dalam konteks, pemilihan kolokasi tunggal yang tepat, perluasan makna kosa kata sedia ada dan yang paling rendah ialah elemen penggunaan kata yang tepat dalam konteks. Dapatan ini turut menyokong dapatan kajian-kajian lepas (Mezah, 2009; Mohamad \& Mezah, 2007; Nawi \& Zainuddin, 2018). Sehubungan itu, kelemahan pengetahuan dan kecekapan kolokasi dalam kalangan pelajar bahasa Arab khususnya pelajar STAM perlu diberi perhatian serius memandangkan keperluan saiz yang tinggi dan kedalaman kosa kata bahasa Arab yang mantap bagi memastikan kelangsungan pengajian mereka dalam bidang pengajian Islam dan bahasa Arab di peringkat universiti sama ada di dalam atau di luar negara.

Seterusnya, fokus utama kajian ini mendapati wujudnya hubungan positif yang signifikan antara saiz kosa kata dan pengetahuan kolokasi bahasa Arab bahkan perhubungan itu adalah kuat. Di samping itu, hasil kajian juga turut menjelaskan bahawa $57.7 \%$ corak peningkatan faktor pengetahuan kolokasi bahasa Arab dijelaskan oleh saiz kosa kata yang dimiliki oleh pelajar manakala $42.3 \%$ lagi adalah 
berdasarkan faktor lain yang tidak dapat dikesan. Oleh yang demikian, peluang ini perlu dimanfaatkan oleh pelajar dan guru bagi meningkatkan pengetahuan kolokasi bahasa Arab dengan mempelbagaikan strategi serta teknik pembelajaran kolokasi (Asbulah et al., 2019, 2020). Kebergantungan kepada saiz kosa kata semata-mata adalah tidak wajar (Schmitt, 2014).

\section{Kesimpulan}

Tujuan kajian ini adalah untuk mengkaji hubungan antara saiz kosa kata dan pengetahuan kolokasi bahasa Arab. Secara keseluruhan, kajian ini mendapati bahawa tahap saiz kosa kata dan pengetahuan kolokasi bahasa Arab dalam kalangan pelajar STAM berada pada tahap yang sederhana rendah. Oleh itu, pihak yang berkaitan perlu memainkan peranan dalam meningkatkan saiz kosa kata dan pengetahuan kolokasi bahasa Arab dalam kalangan pelajar sebelum meneruskan pengajian ke peringkat yang lebih tinggi bagi melahirkan graduan yang cemerlang dan memiliki kemahiran bahasa yang kompeten. Walau bagaimanapun, kajian ini hanya mengkaji perhubungan saiz kosa kata dan pengetahuan kolokasi bahasa Arab dalam kalangan 150 orang pelajar STAM. Oleh yang demikian, kajian lanjutan perlu dilakukan terhadap pelajar pada peringkat menengah rendah dan tinggi bagi mengetahui tahap penguasaan pelajar secara keseluruhanya. Selain itu, kajian berbentuk kualitatif juga boleh dilakukan terhadap guru dan pelajar STAM untuk mengetahui faktor yang menyebabkan pelajar berada pada tahap sederhana rendah dalam kedua-dua aspek tersebut. Diharapkan kajian sebegini dapat mengisi kelompangan kajian lepas melalui penemuan dapatan yang unik sebagai memberi solusi tambahan kepada isu keterbatasan kosa kata bahasa Arab dan menyumbang pengetahuan baharu dalam kajian kosa kata bahasa Arab dalam kalangan bukan penutur jati.

\section{Rujukan}

Abdul Ghani, K. (2011). Kebolehbacaan buku teks Bahasa Arab Tinggi berasaskan ujian kloz dalam kalangan pelajar di SMKA. GEMA Online Journal of Language Studies, 11(2), 53-66. https://ejournal.ukm.my/gema/article/view/56

Abdul Wahab, U. (2014). Penggunaan penyusun grafik dalam penguasaan kolokasi bahasa Arab [Master's Thesis, Universiti Malaya]. http://studentsrepo.um.edu.my/5397

Abu Abdulla, A. A. M., Muhammad 'Abdullah Abu al-Rab. (2017). Al-Mutalazimat alLafziyyah. Majallah al-Jami'ah al-Islamiyyah lil Buhuth al-Insaniyyah. 25(1), 76-89. http://dx.doi.org/10.33976/iugjhr.v25i1.1995

Ahmad, J. (2002). Pemupukan budaya penyelidikan di kalangan guru di sekolah: Satu penilaian [Unpublished doctoral dissertation]. Universiti Kebangsaan Malaysia.

Aladdin, A. (1998). Kekeliruan antara al-idafat dan al-na'at di kalangan pelajar Melayu [Unpublished master's thesis]. Universiti Malaya. 
Aladdin, A. (2012). Analisis penggunaan strategi komunikasi dalam komunikasi lisan Bahasa Arab. GEMA Online Journal of Language Studies, 12(2), 645-666. https://ejournal.ukm.my/gema/article/view/632

al-Tahir 'Abd al-Salam, H. (2004). Mu'jam al-Hafiz li al-Mutasahibat al-'Arabiyyah. Maktabah Lubnan Nasyirun.

Asbulah, L. H., Aladdin, A., \& Sahrim, M. (2020). The level of students' engagement in Arabic within public universities. Asia Pacific Journal of Educators and Education, 35(1), 1-16. https://doi.org/10.21315/apjee2020.35.1.1

Asbulah, L. H., Aladdin, A., Lubis, M. A., \& Sahrim, M. (2019). Arabic collocation learning strategies among students of Malaysian public universities. GEMA Online Journal of Language Studies, 19(2), 139-159. https://doi.org/10.17576/gema-2019-1902-09

Bağci, N. D. (2014). Turkish university level EFL learners' collocational knowledge at receptive and productive levels. [Master's thesis]. Middle East Technical University. https://open.metu.edu.tr/handle/11511/24109

Baharudin, H., \& Ismail, Z. (2014). Vocabulary learning strategies and Arabic vocabulary size among pre-university students in Malaysia. International Education Studies, 7(13), 219-226. https://doi.org.10.5539/ies.v7n13p219

Bahns, J., \& Eldaw, M. (1993). Should we teach EFL students collocations? System, 21(1), 101-114. https://doi.org/10.1016/0346251X(93)90010-E

Basal, A. (2019). Learning collocations: Effects of online tools on teaching English adjective-noun collocations. British Journal of Educational Technology, 50(1), 342-356. https://doi.org/10.1111/bjet.12562

Bergström, K. (2008). Vocabulary and receptive knowledge of English collocations among Swedish upper secondary school students [Unpublished master's thesis]. Stockholm University.

Chua, Y. P. (2014). Asas statistik penyelidikan (3rd ed.). McGraw-Hill Education.

Daud, N., \& Pisal, N. A. (2014). Permasalahan pertuturan dalam bahasa Arab sebagai bahasa kedua. GEMA Online Journal of Language Studies, 14(1), 117-133. http://dx.doi.org/10.17576/GEMA-2014-1401-08

Fernández, B. G., \& Schmitt, N. (2015). How much collocation knowledge do L2 learners have? ITL-International Journal of Applied Linguistics, 166(1), 94-126. https://doi.org/10.1075/itl.166.1.03fer

Gyllstad, H. (2007). Testing English collocations: Developing receptive tests for use with advanced Swedish learners. Språk-och litteraturcentrum, Lunds Universitet.

Hair, J. F., Anderson, R. E., Babin, B. J., \& Black, W. C. (2010). Multivariate data analysis: A global perspective (7th ed.). Prentice Hall.

Hazwan, M. (2018). Mustawa Iktisab al-Mufradat al-Lughawiyyah lada Talabah alMarkaz al-Tamhidi bi Jami'ah al-'ulum al-Islamiyyah al-Maliziyyah [Unpublished doctoral dissertation]. Universiti Sains Islam Malaysia.

Hellman, A. B. (2011). Vocabulary size and depth of word knowledge in adult-onset second language acquisition. International Journal of Applied Linguistics, 21(2), 162-182. https://doi.org/10.1111/j.1473-4192.2010.00265.x 
Hill, J. (2000). Revising priorities: from grammatical failure to collocation success. In M. Lewis (Eds.), Teaching collocation: Further developments in the lexical approach (pp. 47-69). Language Teaching Publications.

Kadlecová, D. (2014). L2 collocations and the L2 mental lexicon [Unpublished master's thesis]. Utrecht University.

Koizumi, R., \& In'nami, Y. (2020). Structural Equation Modeling of vocabulary size and depth using conventional and Bayesian methods. Frontiers in Psychology, 11, 618. https://doi.org/10.3389/fpsyg.2020.00618

Konting, M. M. (1990). Kaedah penyelidikan pendidikan. Dewan Bahasa dan Pustaka.

Laufer, B., \& Nation, I. S. P. (2013). Vocabulary. In S. M. Gass \& A. Mackey (Eds.), The Routledge handbook of second language acquisition (pp. 181-194). Routledge.

Laufer, B., \& Waldman, T. (2011). Verb-noun collocations in second language writing: A corpus analysis of learners' English. Language Learning, 61(2), 647-672. https://doi.org/10.1111/j.1467-9922.2010.00621.x

Lewis, M. (2000). Teaching collocation: Further developments in the lexical approach. Language Teaching Publications.

Mansoor, M. S. (2019). Collocational competence via awareness-raising. Journal of Al-Frahedis Arts/مجلة $\quad 33$ آداب 13-32. http://dx.doi.org/10.25130/art.v0i33.35

Meara, P. (1997). Towards a new approach to modelling vocabulary acquisition. In N. Schmitt \& M. McCarthy (Eds.), Vocabulary: Description, acquisition and pedagogy (pp. 109-121). Cambridge University Press.

Meara, P. M., \& Alcoy, J. C. O. (2010). Words as species: An alternative approach to estimating productive vocabulary size. Reading in a Foreign Language, 22(1), 222-236.

Mezah, C. R. (2009). Kesilapan leksikal dalam pembelajaran bahasa Arab. Penerbit Universiti Putra Malaysia.

Mezah, C. R. (2010). Pengajaran bahasa Arab himpunan pedoman buat guru dan bakal guru siri 1. Penerbit Universiti Putra Malaysia.

Milton, J. (2009). Measuring second language vocabulary acquisition. Multilingual Matters. https://doi.org/10.21832/9781847692092

Mohamad, A. B., \& Mezah, C. R. (2007). Kolokasi: Aspek penting dalam penguasaan bahasa Arab: Satu kajian di kalangan pelajar IPTA. In Ab. Aziz, S., Konting, M. M., \& Ahmad, M. (Eds.), Persidangan pengajaran dan pembelajaran di peringkat pengajian tinggi (CTLHEO7) (pp. 139-148). Pusat Pembangunan Akademik (CADe). http://psasir.upm.edu.my/id/eprint/20342/

Mutlu, G., \& Kaşlioğlu, Ö. (2016). Vocabulary size and collocational knowledge of Turkish EFL learners/İngilizceyi Yabancı Dil Olarak Öğrenen Türk Öğrencilerin Kelime Dağarcığı ve Eşdizim Bilgisi. Eğitimde Kuram ve Uygulama, 12(6), 12311252.

Nation, I. S. P. (2001). Learning vocabulary in another language. Cambridge University Press.

Nation, P. \& Waring, R. (1997). Vocabulary size, text coverage and word lists. In N. Schmitt \& M. McCarthy (Eds.), Vocabulary: description, acquisition and pedagogy (pp. 6-19). Cambridge University Press. 
Nawi, A., \& Zainuddin, N. (2018). Ittijahat al-Mu'allimin fi Tadris al- Mutalazimat alLafziyyah li al-Muta'allimin ghayr al-Natiqin bi al-Lughah al-'Arabiyyah fi Marhalah al-I'dad al-Jami'iy. Al-Ḍ̄d Journal, 2(1), 29-48.

Nizonkiza, D. (2012). Quantifying controlled productive knowledge of collocations across proficiency and word frequency levels. Studies in Second Language Learning and Teaching, 2(1), 67-92. https://doi.org/10.14746/ssllt.2012.2.1.4

Noor, Z. A. M., Yusoff, N. M. R. N., Yasim, I. M. M., \& Kamarudin, M. Y. (2016). Foreign language vocabulary learning strategies in Malaysia. Creative Education, 7(3), 428-434.

Nunnally, J. C. (1978). Psychometric theory (2nd ed.). McGraw-Hill.

Nunnally, J. C., \& Bernstein, I. H. (1994). Psychometric theory. McGraw-Hill.

Rahimi, N. M., Hussin, Z., \& Normeza, W. (2014). Pembelajaran kosa kata bahasa Arab secara aturan kluster semantik dan aturan kluster bebas. Sains Humanika, 67(1), 33-38. https://doi.org/10.11113/sh.v67n1.126

Razak, Z. R. A., \& Samah, R. (2018). Saiz kosa kata bahasa Arab dalam kalangan pelajar di peringkat pengajian tinggi: Permasalahan dan strategi pengajaran. International Journal of Language Education and Applied Linguistics, 8(2), 61-70.

Razak, Z. R. A., Samah, R., Jumingan, M. F., \& Bakar, M. S. A. (2015). Kosa kata penting di peringkat STAM: Analisis korpus dalam buku teks. Sains Humanika, 5(1), 43-49. https://doi.org/10.11113/sh.v5n1.358

Read, J. (2000). Assessing vocabulary. Cambridge University Press.

Read, J. (2013). Validating a test to measure depth of vocabulary knowledge. In A. J. Kunnan (Ed.), Validation in language assessment (pp. 55-74). Routledge.

Said, G. H. (2014). Qamus al-Mutalazimat al-Lafziyyah wa al-ibarat al-Siyaqiyyah 'Arabiy-Injiliziy. Maktabah Lubnan Nasyirun.

Samah, R. (2012). Pembinaan ayat bahasa Arab dalam kalangan lepasan sekolah menengah agama. GEMA Online Journal of Language Studies, 12(2), 555-569.

Santillàn Grimm, P. (2009). Collocation in Modern Standard Arabic revisited. Zeitschrift für Arabische Linguistik, 51, 22-41.

Santillàn Grimm, P. (2010). Teaching collocation in the Arabic as a foreign language class. In V. Aguilar, L. M. Pèrez Cańada, \& P. Santillàn Grimm (Eds.), Enseñanza y aprendizaje de la lengua árabe: ARABELE 2009 (pp. 163-177). Universidad de Mursia.

Schmitt, N. (2000). Vocabulary in language teaching. Cambridge University Press.

Schmitt, N. (2010). Researching vocabulary: A vocabulary research manual. Palgrave Macmillan.

Schmitt, N. (2014). Size and depth of vocabulary knowledge: What the research shows. Language Learning, 64(4),

913-951. https://doi.org/10.1111/lang.12077

Siyanova, A., \& Schmitt, N. (2008). L2 learner production and processing of collocation: A multi-study perspective. The Canadian Modern Language Review/La revue canadienne des langues vivantes, 64, 429-458. https://doi.org/10.3138/cmlr.64.3.429 
Sonbul, S., \& Schmitt, N. (2013). Explicit and implicit lexical knowledge: Acquisition of collocations under different input conditions. Language Learning, 63(1), 121-159. https://doi.org/10.1111/j.1467-9922.2012.00730.x

Umar, A. M. (1998). Ilmu dilalah. 'Alam al-Kutub.

Vermeer, A. (2001). Breadth and depth of vocabulary in relation to L-1/L-2 acquisition and frequency of input. Applied Psycholinguistics, 22, 217-234. https://doi.org/10.1017/S0142716401002041

Webb, S. (2012). Depth of vocabulary knowledge. In A. C. Carol (Ed.), The encyclopedia of applied linguistics (pp. 1656-1663). Blackwell Publishing Ltd.

Wray, A. (2002). Dual processing in protolanguage: performance without competence. In A. Wray (Ed.), The transition to language (pp. 113-137). Oxford University Press.

Yusri, G., Rahimi, N. M., Shah, P. M., \& Wah, W. H. (2011). Cognitive and metacognitive learning strategies among Arabic language students. Interactive Learning Environments, 21(3), https://doi.org/10.1080/10494820.2011.555840

Zaini, A. R., \& Abd. Rahman, M. Z. (2017). Saiz kosa kata Bahasa Arab dan hubungannya dengan kemahiran bertutur. Jurnal Sultan Alauddin Sulaiman Shah, 4(1), 220-228. 


\section{LAMPIRAN 1}

\section{Jadual 1}

Interpretasi skor min ujian saiz kosa kata Bahasa Arab dan ujian kolokasi Bahasa Arab

\begin{tabular}{ccc}
\hline Skor min & Skor min & Interpretasi tahap \\
(Ujian Saiz Kosa Kata Arab) & (Ujian Kolokasi Bahasa Arab) & \\
\hline $31-40$ & $35-45$ & Tinggi \\
$21-30$ & $24-34$ & Sederhana tinggi \\
$11-20$ & $13-23$ & Sederhana rendah \\
$00-10$ & $00-12$ & Rendah \\
\hline
\end{tabular}

(Adaptasi dari Nunally, J.C dan Bernstein, I.H, (1994) Psychometric Theory (3 ${ }^{\text {rd }}$ ed), New York: McGraw-Hill)

\section{Jadual 2}

Interpretasi skor min elemen pengetahuan kolokasi dalam ujian kolokasi Bahasa Arab

\begin{tabular}{|c|c|}
\hline $\begin{array}{c}\text { Skor min } \\
\text { Elemen Pengetahuan Kolokasi } \\
\text { Bahasa Arab }\end{array}$ & Interpretasi \\
\hline $7-9$ & Tinggi \\
\hline $4-6$ & Sederhana \\
\hline $0-3$ & Rendah \\
\hline
\end{tabular}

(Adaptasi dari Ahmad \& Meerah, 2002). Pemupukan budaya penyelidikan di kalangan guru di sekolah: Satu penilaian. Penerbit Universiti Kebangsaan Malaysia)

Jadual 3

Nilai panduan korelasi linear Pearson $r$

\begin{tabular}{ccl}
\hline $\begin{array}{c}\text { Nilai Julat Korelasi } r \\
\text { [Positif] }\end{array}$ & $\begin{array}{c}\text { Nilai Julat Korelasi } r \\
\text { [Negatif] }\end{array}$ & $\begin{array}{c}\text { Interpretasi } \\
\text { Hubungan Korelasi }\end{array}$ \\
\hline $\begin{array}{c}\text { 0.80 hingga } 1.00 \\
\text { 0.60 hingga } 0.79\end{array}$ & $\begin{array}{c}(-0.80) \text { hingga }(-1.00) \\
(-0.60) \text { hingga }(-0.79)\end{array}$ & sangat kuat \\
0.40 hingga 0.59 & $(-0.40)$ hingga $(-0.59)$ & sederhana \\
0.20 hingga 0.39 & $(-0.20)$ hingga $(-0.39)$ & lemah \\
0.00 hingga 0.19 & 0.00 hingga $(-0.19)$ & sangat lemah \\
\hline
\end{tabular}

Sumber: Hair, J. F., Wolfinberger, M. F., Ortinau, D. J., \& Bush, R. P. (2010). Essentials of marketing research ( $2^{\text {nd }}$ ed.). New York: McGraw-Hill. 